\title{
METHODS OF METOPROLOL ANALYSIS IN DRUGS AND BIOLOGICAL FLUIDS: REVIEW AND SUGGESTIONS
}

\author{
M.M. Horyn, *L.S. Logoyda \\ I. HORBACHEVSKY TERNOPIL NATIONAL MEDICAL UNIVERSITY, TERNOPIL, UKRAINE
}

Background. Analytical method is increasingly implemented into fundamental pharmaceutical chemistry and analysis, considering their high sensitivity, accuracy, specificity and expressiveness.

Objective. Metoprolol's analytical method development was the research goal.

Methods. The sources were world recognized journals (1990-2019) and key words used as filter were "metoprolol", "spectrophotometry" "high-performance liquid chromatography, HPLC", "quantitative analysis", "validation".

Results. Chromatographic methods of analysis have the highest specificity and objectivity and allow qualitative and quantitative determination of Active Pharmaceutic Ingredient (API) in combined dosage forms and biological fluids without prior components separation. The main disadvantage of the described API analysis methods is long terms from the beginning of chromatography to API release and specific solvents used as the mobile phase in HPLC. New methods development and selection such chromatographic conditions that provide high speed and high efficiency at lower pressure of the system are essential. Also, the reduction of analysis time is achieved by simplifying the conditions for sample preparation.

Conclusions. Analysts are constantly working on developing new analysis methods and their optimization in order to save time and consumables, which also ensures the efficiency of the developed method. There is no monograph on the substance or dosage forms of metoprolol in SPhU. Therefore, some of the developed methods should be suggested for the SPhU monograph, which is important for ensuring pharmacopoeial quality control of medicines in Ukraine.

KEY WORDS: metoprolol; spectrophotometry; high-performance liquid chromatography; quantitative analysis; method development; validation.

\section{Introduction}

The quality of treatment depends much on the bioavailability of the medicinal product, which in turn is influenced by the correct and effective pharmaceutical development. Antihypertensive drugs are currently the most widely used medicines, which is associated with increase in the population with high blood pressure and those at risk for stroke and other serious diseases of the cardiovascular system. Considerable demand for antihypertensive drugs in tablet form is a prerequisite for inclusion of a large number of generic drugs in the range of industrial enterprises. The main task of pharmaceutical development for such drugs is to develop a composition that will provide bioavailability comparable to the original. The efficacy and correctness of pharmaceutical development must be confirmed by bioequiCorresponding Author: Logoyda L.S., Ph.D., DSC, Head of Department of Pharmaceutical Chemistry, I. Horbachevsky Ternopil National Medical University, 1 Maidan Voli, Ternopil, Ukraine. E-mail: logojda@tdmu.edu.ua valence studies by in vivo and in vitro methods. For these purposes, effective and reliable methods for detection of API in biological fluids should be developed. It is generally accepted to use chromatographic methods for this purpose that can provide sufficient selectivity and accuracy of determination even at relatively low doses. It should be noted that today the requirements for bioanalytical techniques are framework and too broad to be universal. Therefore, making proposals for the study of individual validation characteristics for pharmacokinetic purposes is very important. There are currently no systematic studies of metoprolol.

Metoprolol succinate is a beta1-selective (cardioselective) adrenoceptor blocking agent, for oral administration, available as extendedrelease tablets. Metoprolol succinate extendedrelease tablet has been formulated to provide a controlled and predictable release of metoprolol for once-daily administration. The tablets 
comprise a multiple unit system containing metoprolol succinate in a multitude of controlled release pellets. Each pellet acts as a separate drug delivery unit and is designed to deliver metoprolol continuously over the dosage interval. The tablets contain 23.75, 47.5, 95 and $190 \mathrm{mg}$ of metoprolol succinate equivalent to $25,50,100$ and $200 \mathrm{mg}$ of metoprolol tartrate, USP, respectively. Its chemical name is $( \pm)$ 1-(isopropylamino)-3-[p-(2-methoxyethyl) phenoxy]-2-propanol succinate (2:1) (salt) (Fig.1). Metoprolol is a propanolamine that is 1-(propan-2-ylamino)propan-2-ol substituted by a 4-(2-methoxyethyl)phenoxy group at position 1. It acts as a beta-adrenergic antagonist, an antihypertensive agent, a xenobiotic and an environmental contaminant. It is a propanolamine, an aromatic ether, a secondary alcohol and a secondary amino compound. Metoprolol is used for a number of conditions, including hypertension, angina pectoris, acute myocardial infarction, different types of tachyarrythmia, congestive heart failure, and prevention of migraines. Due to its selectivity, metoprolol is also prescribed for off-label use for anxiety disorders. Metoprolol blocks $\beta 1$ drenergic receptors in cardiomyocytes, thereby decreasing the slope of phase 4 in the nodal action potential (reducing $\mathrm{Na}^{+}$uptake) and prolonging repolarization of phase 3 (slowing down $\mathrm{K}^{+}$release). It suppresses the norepinephrine-induced increase in the sarcoplasmic reticulum $\mathrm{Ca}^{2+}$ leak and the spontaneous $\mathrm{SR} \mathrm{Ca}^{2+}$ release, which are the major triggers for atrial fibrillation.<smiles>COCCc1ccc(OCC(O)CNC(C)C)cc1</smiles>

Fig. 1. Chemical structure of metoprolol.

Within the UK, metoprolol is classified as a prescription-only drug in the beta blocker class and is regulated by the Medicines and Healthcare Products Regulatory Agency (MHRA). The MHRA is a government body set up in 2003 and is responsible for regulating medicines, medical devices, and equipment used in healthcare. In the U.S. use of beta blockers such as metoprolol was approved by the Food and Drug Administration (FDA) in 1967 for the treatment of cardiac arrhythmias, hypertension, migraines, and others. Prescribers may choose to prescribe beta blockers for other treatments if there is just cause even though it is not approved by the FDA. Drug manufacturers, however, are unable to advertise beta blockers for other purposes that have not been approved by the FDA. Since the FDA does not regulate the practice of medicine after the drug has been approved, it is legal to prescribe beta blockers for other treatments such as performance anxiety. In man, absorption of metoprolol is rapid and complete. Plasma levels following oral administration of conventional metoprolol tablets, however, approximate $50 \%$ of levels following intravenous administration, indicating about $50 \%$ first-pass metabolism. Metoprolol crosses the blood-brain barrier and has been reported in the CSF in a concentration $78 \%$ of the simultaneous plasma concentration. Plasma levels achieved are highly variable after oral administration. Only a small fraction of the drug (about 12\%) is bound to human serum albumin. Metoprolol is a racemic mixture of $\mathrm{R}$ - and S-enantiomers, and is primarily metabolized by CYP2D6. When administered orally, it exhibits stereoselective metabolism that is dependent on oxidation phenotype. Elimination is mainly by biotransformation in the liver, and the plasma half-life ranges from approximately 3 to 7 hours. Less than $5 \%$ of an oral dose of metoprolol is recovered unchanged in the urine; the rest is excreted by the kidneys as metabolites that appear to have no betablocking activity. Following intravenous administration of metoprolol, the urinary recovery of unchanged drug is approximately $10 \%$. The systemic availability and half-life of metoprolol in patients with renal failure do not differ to a clinically significant degree from those in normal subjects. Consequently, no reduction in dosage is usually needed in patients with chronic renal failure. Metoprolol is metabolized predominantly by CYP2D6, an enzyme that is absent in about $8 \%$ of Caucasians (poor metabolizers) and about $2 \%$ of most other populations. CYP2D6 can be inhibited by a number of drugs. Concomitant use of inhibiting drugs in poor metabolizers will increase blood levels of metoprolol several-fold, decreasing metoprolol's cardioselectivity. Metoprolol has a very low melting point; around $120^{\circ} \mathrm{C}\left(248^{\circ} \mathrm{F}\right)$ for the tartrate, and around $136^{\circ} \mathrm{C}\left(277^{\circ} \mathrm{F}\right)$ for the succinate. Because of this, metoprolol is always manufactured in a salt-based solution, as drugs with low melting points are difficult to work with in a manufacturing environment. The free base exists as a waxy white solid, and the tartrate salt is finer crystalline material. 
Metoprolol contains a stereocenter and consists of two enantiomers. Metoprolol succinate is a white crystalline powder with a molecular weight of 652.8. It is freely soluble in water; soluble in methanol; sparingly soluble in ethanol; slightly soluble in dichloromethane and 2-propanol; practically insoluble in ethylacetate, acetone, diethylether and heptane. Inactive ingredients: silicon dioxide, cellulose compounds, sodium stearyl fumarate, polyethylene glycol, titanium dioxide, paraffin. Physico-chemical analysis methods are increasingly introduced into fundamental pharmaceutical research and pharmaceutical analysis practice, taking into account their high sensitivity, accuracy, specificity and expressiveness.

Objective was analytical method development for metoprolol.

\section{Methods}

Literature survey has been done in range of years 1990-2019 to make the review updated and comprehensive and to show the new approaches to development of the methods of metoprolol analysis. The sources were world recognized journals and key words used as filter were metoprolol, spectrophotometry, highperformance liquid chromatography, quantitative analysis, method development, validation [1-5].

\section{Results}

Pharmacopeian methods of analysis of metoprolol are presented in Fig. 2. The State Pharmacopoeia of Ukraine (SPhU) has not developed a monograph on the substance of metoprolol or on the prepared medical form yet. However, the United States Pharmacopoeia regulates the determination of metoprolol succinate in extended-release tablets. For identification, IR-spectroscopy and HPLC are suggested; for quantitative determination of metoprolol succinate in tablets in assay and dissolution test - HPLC, respectively. Chromatographic conditions for determination of metoprolol succinate in tablets are specified in the monograph of the United States Pharmacopoeia, which are used the chromatographic column 4-mm $\times 12.5-\mathrm{cm}$; $5-\mu \mathrm{m}$ packing $\mathrm{L} 7$ and mobile phase consisting of acetonitrile and buffer (25:75). Mobile phase rate $-1 \mathrm{ml} / \mathrm{min}$, detection wavelength $-280 \mathrm{~nm}$, tailing factor NMT 2.0, relative standard deviation - NMT $2.0 \%$.

The suggested method of the United States Pharmacopeia requires a long sampling. The European Pharmacopeia has a monograph on metoprolol tartrate tablets. Identification of metoprolol tartrate of the European Pharmacopeia regulates the absorption spectrophotometry in the infrared region, UV-spectropho-

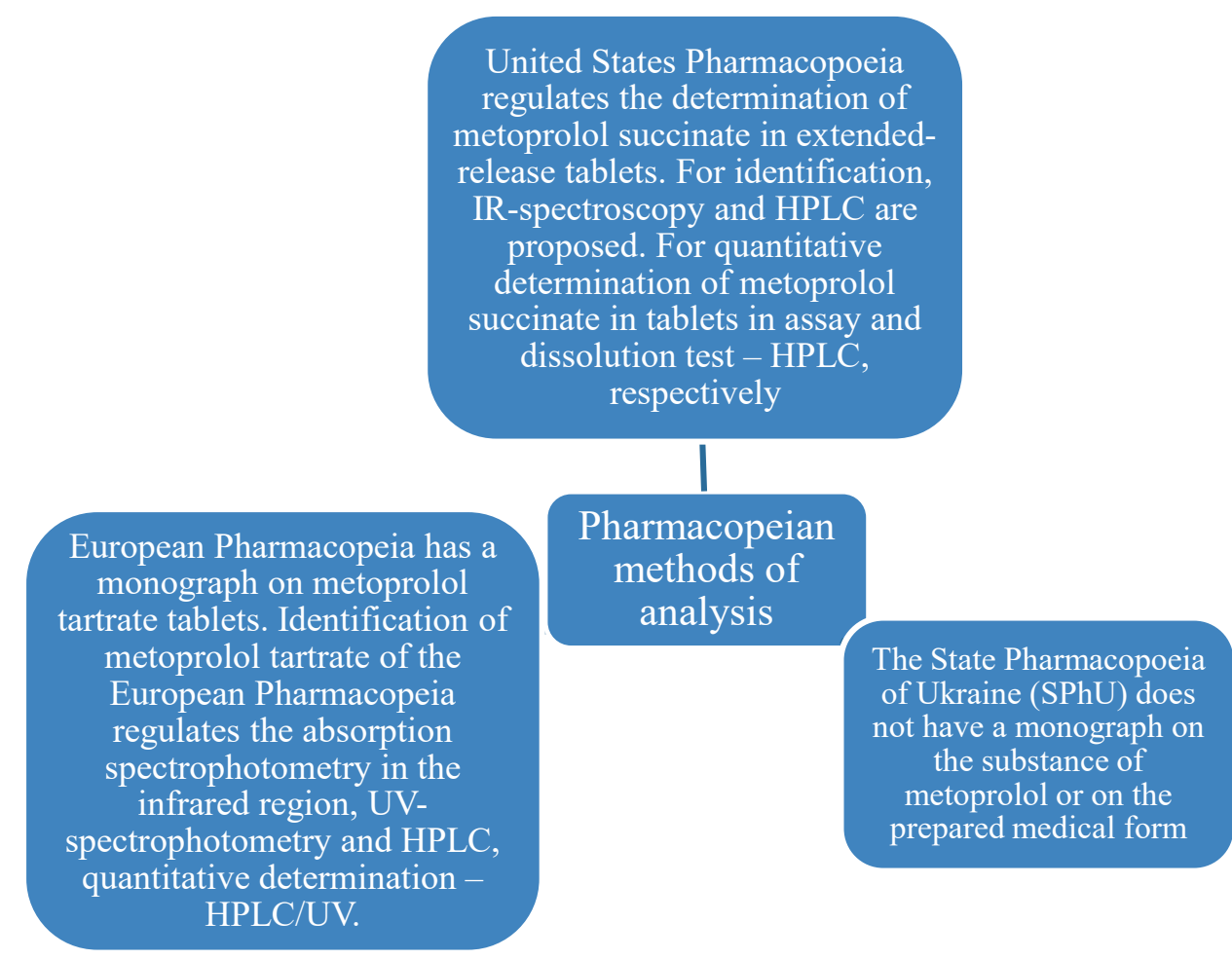

Fig. 2. Pharmacopeian methods of analysis of metoprolol. 
tometry and HPLC, quantitative determination HPLC/UV. As a solvent, a mixture of methanol and $0.1 \mathrm{M}$ hydrochloric acid is used, mobile phase - solution of 1-pentanesulfonic acid sodium salt (monohydrate), anhydrous sodium acetate in mixture of methanol and water and adding glacial acetic acid. Mobile phase rate $1.0 \mathrm{ml} / \mathrm{min}$, detection wavelength - $254 \mathrm{~nm}$.

Historical development of methods for the quantitative determination of metoprolol in substances and drugs is related to the development of analytical methods only and pharmaceutical analysis in general. Nowadays the literature contains a large number of scientific papers devoted to the quantitative determination of metoprolol and other APIs in one medical form, since metoprolol is used in combination with different APIs for the treatment of hypertension. According to the literature data, spectrophotometry [6-11], HPLC [12-21], gas chromatography [22] are the most widely used techniques for the determination of metoprolol tartrate.

Mustafa Cesme et al. suggested spectrophotometric determination of metoprolol tartrate in pharmaceutical dosage forms on complex formation with Cu(II). Spectrophotometric method has been developed for the assay of metoprolol tartrate, which is based on the complexation of drug with copper(II) [Cu(II)] at pH 6.0, using Britton-Robinson buffer solution, to produce a blue adduct. The latter has a maximum absorbance at $675 \mathrm{~nm}$ and obeys Beer's law within the concentration range $8.5-70 \mu \mathrm{g} / \mathrm{mL}$. Regression analysis of the calibration data showed a good correlation coefficient $(r=0.998)$ with a limit of detection of $5.56 \mu \mathrm{g} / \mathrm{mL}$. The suggested procedure has been successfully applied to the determination of this drug in its tablets. In addition, the spectral data and stability constant for the binuclear copper(II) complex of metoprolol tartrate $\left(\mathrm{Cu}_{2} \mathrm{MPT}_{2} \mathrm{Cl}_{2}\right)$ have been reported [6].

Two simple and selective spectrophotometric methods are described for determination of metoprolol tartar as base form metoprolol in bulk drug, and in tablets and capsules by Nabil A.F., Eman M.S. The methods are based on the molecular charge transfer complexation of metoprolol base metoprolol with Bromothymol blue (BTB) or 2,3-Dichloro-5,6-dicyano-1,4benzoquinone (DDQ). The yellow and orange colored radical anions formed on dissociation, are quantitated at $413 \mathrm{~nm}$ (BPB method) or 457 $\mathrm{nm}$ (DDQ method). The assay conditions were optimized. Beer's law is obeyed in the concen- tration ranges 2.0-40.0 $\mathrm{mg} \mathrm{mL}^{-1}$ in BPB method and 5.0-25.0 $\mu \mathrm{g} \cdot \mathrm{mL}^{-1}$ in DDQ method, with respective molar absorptivity values of $5.78 \times 103$ and $4.05 \times 103 \mathrm{~L} \mathrm{~mol}^{-1} \cdot \mathrm{cm}^{-1}$. The reaction stoichiometry in both methods was evaluated by Job's method of continuous variations and was found to be 1:1 MPT-BPB, MPT-DDQ. The developed methods were successfully applied to the determination of metoprolol in pure form and commercial tablets with good accuracy and precision. Statistical comparison of the results was performed using Student's t-test and Fratio at 95\% confidence level and the results showed no significant difference between the reference and suggested methods with regard to accuracy and precision. Further, the accuracy and reliability of the methods were confirmed by recovery studies via standard addition technique [7].

Ukrainian scholars Anastasiia Donchenko and Svitlana Vasyuk suggested spectrophotometric determination of metoprolol tartrate in pure and dosage forms. This method is based on the reaction between metoprolol tartrate and 2,3-dichloro-1,4-naphthoquinone in dimethylformamide (DMF) medium to form the colored reaction product with maximum absorption at $493 \mathrm{~nm}$. Optimum conditions to carry out the reaction such as concentration of reagent, temperature and heating time were carefully studied and optimized. Beer's law was performed at the concentration range of 18.00$28.00 \mathrm{mg} / 100 \mathrm{ml}$. The suggested method is valid according to the validation requirements of SPhU [8].

Turkish scientist Yilmaz B. developed determination of metoprolol in pharmaceutical preparations by zero-, first-, second- and thirdorder derivative spectrophotometric method. Zero-, first-, second- and third-order derivative spectrophotometry methods were developed for determination of metoprolol in pharmaceutical preparations. In zero order spectrophotometry, absorbance values were measured at $276 \mathrm{~nm}$ in zero order spectra of solution of metoprolol in methanol in the range of 240$310 \mathrm{~nm}$. In the first derivative spectrophotometry, absorbance values were measured at 265, 278 and $285 \mathrm{~nm}$. In the second derivative spectrophotometry, absorbance values were measured at $276,279,287$ and $282 \mathrm{~nm}$. In the third derivative spectrophotometry, absorbance values were measured at 275, 278 and $281 \mathrm{~nm}$. Parameters such as linearity, precision, accuracy, specificity, stability, limit of detection and limit of quantitation were studied according to the International Conference on Harmonization Guide- 
lines. All the methods developed were successfully applied to two tablet formulation and the results were compared statistically with each other [9].

Jadhav A.S. et al. suggested UV spectrophotometric methods for estimation of metoprolol succinate from bulk and tablet formulation in phosphate buffer 6.8. The drug obeyed the Beer's law with correlation coefficient 0.9999 and 0.9979 respectively for method I and method II. It showed absorption maxima at $223 \mathrm{~nm}$ and $226 \mathrm{~nm}$ respectively for method I and method II; in phosphate buffer 6.8. The linearity was observed between 5 and $25 \mu \mathrm{g} / \mathrm{mL}$. The results of analysis were validated by recovery studies, accuracy, precision, LOD, LOQ and ruggedness. The method was found to be simple, accurate, precise, economical and robust [10].

Rahman N. et al. have developed validated kinetic spectrophotometric method for determination of metoprolol tartrate in pharmaceutical formulations. The method is based on reaction of the drug with alkaline potassium permanganate at $25+/-1$ degrees $C$. The reaction is followed spectrophotometrically by measuring the change in absorbance at $610 \mathrm{~nm}$ as a function of time. The initial rate and fixed time (at $15.0 \mathrm{~min}$ ) methods are utilized for constructing the calibration graphs to determine the concentration of the drug. Both the calibration graphs are linear in the concentration range of $1.46 \times 10^{-6}-8.76 \times 10^{-6} \mathrm{M}$ (10.0-60.0 microg per $10 \mathrm{ml})$. The calibration data resulted in the linear regression equations of $\log ($ rate $)=3.634+$ $0.999 \log C$ and $A=6.300 \times 10^{-4}+6.491 \times 10^{-2} C$ for initial-rate and fixed time methods, respectively. The limits of quantitation for initial rate and

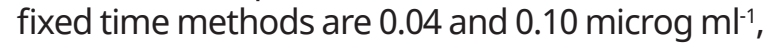
respectively. The activation parameters such as $\mathrm{E}(\mathrm{a})$, DeltaH(double dagger), DeltaS(double dagger) and DeltaG(double dagger) are also evaluated for the reaction and found to be $90.73{\mathrm{~kJ} \in \mathrm{mol}^{-1}, 88.20 \mathrm{~kJ} \mathrm{~mol}}^{-1}, 84.54 \mathrm{~J} \cdot \mathrm{K}^{-1} \cdot \mathrm{mol}^{-1}$ and $63.01 \mathrm{~kJ} \cdot \mathrm{mol}^{-1}$, respectively. The results are validated statistically and through recovery studies. The method has been successfully applied to the determination of metoprolol tartrate in pharmaceutical formulations. Statistical comparison of the results with the reference method shows excellent agreement and indicates no significant difference in accuracy and precision [11].

The HPLC method is widely used in the analysis of metoprolol both in substance and in mono- and combined drugs. Simple, precise, sensitive methods are developed today: liquid chromatography, combination of TLC with densitometric determination, HPLC/UV, HPLC/ DMD, HPLC/MS. A reverse phase HPLC method has been developed for the quantitative estimation of amlodipine besylate and metoprolol tartrate in tablet by Hussain S. et al. The quantification was carried out using RP stainless steel column ODS C18 $250 \times 4.6 \times 5 \mu$ L1 packing in isocratic mode with mobile phase containing $0.03 \mathrm{M}$ phosphate buffer and acetonitrile in the ratio of 32: $68(\mathrm{pH} 3.5)$. Flow rate of $1.2 \mathrm{ml} / \mathrm{min}$ and the detection wavelength were set at $230 \mathrm{~nm}$ and the linearity was found to be in the range of $8-12 \mathrm{ig} / \mathrm{ml}$ for amlodipine besylate and metoprolol tartrate. The suggested method was found to be simple, precise, accurate, and reproducible for the estimation of amlodipine besylate and metoprolol tartrate [12].

Singh Brijesh et al. suggested ReversePhase HPLC method for simultaneous analysis of metoprolol succinate and hydrochlorothiazide in a tablet formulation. The drugs were analyzed by a reverse phase $\mathrm{C}-18$ column using $50 \mathrm{mM}$ di-sodium hydrogen phosphate:methanol:acetonitrile in a ratio of 525:225:250 as mobile phase. The flow rate was $1 \mathrm{ml} / \mathrm{min}$ and the compounds were detected by a UV-detector at $222 \mathrm{~nm}$ at a column temperature of $24 \pm 2{ }^{\circ} \mathrm{C}$. The method was statistically validated for linearity and accuracy. The retention time and drug content of metoprolol succinate and hydrochlorothiazide were $5.38 \mathrm{~min}, 96.05 \%$ and 3.04 min., $97.64 \%$, respectively [13].

Simultaneous estimation of metoprolol tartrate and chlorthalidone by using RP-HPLC and method development as per ICH guidelines has been suggested by P. Hari Prasad et al. The chromatographic analysis was performed on a C18column grace smart RP18 $(250 \times 4.6 \mathrm{~mm}$, $5 \mu \mathrm{m})$ in isocratic mode, the mobile phase consisted of methanol, acetonitrile and $0.05 \mathrm{M}$ phosphate buffer (adjusted topH 4.5 with orthophosphoric acid) at a ratio of $60: 20: 20 \mathrm{v} / \mathrm{v} / \mathrm{v}$, and a flow rate of $1.0 \mathrm{~mL} / \mathrm{min}$ and the ASPD detector was used. The eluents were monitored at $254 \mathrm{~nm}$. The retention time of lamivudine and stavudine were found to be $2.50 \mathrm{~min}$ and $4.25 \mathrm{~min}$, respectively. The linear ranges were found to be $10-6022 \mu \mathrm{g} / \mathrm{mL}(r=0.9992)$ for lamivudine and $10-60 \mu \mathrm{g} / \mathrm{mL}(r=0.999)$ for stavudine. The suggested method is also found to be accurate, precise and robust. The method could be applied to routine quality control of pharmaceutical formulations containing metoprolol tartrate and chlorthalidone [14]. 
A simple, rapid, accurate, precise, selective, and reproducible stability-indicating HPLC method has been developed for simultaneous estimation of metoprolol succinate and telmisartan using a mobile phase consisting mixture of Methanol: $10 \mathrm{mM}$ potassium dihydrogen phosphate buffer: $10 \mathrm{mM}$ hexane sulphonic acid $(80: 10: 10, \mathrm{v} / \mathrm{v} / \mathrm{v})$ at the flow rate of $1 \mathrm{~mL} / \mathrm{min}$ and detection wavelength at $223.0 \mathrm{~nm}$ by S. P. Mahaparale et al.. HiQ Sil $C_{18}(250 \times 4.6 \mathrm{~mm}$, $5 \mu \mathrm{m}$ ) column was used as stationary phase. The retention time for metoprolol succinate and telmisartan were $3.067 \mathrm{~min}$ and $5.653 \mathrm{~min}$, respectively. Linearity was observed in the concentration range of $5-80 \mu \mathrm{g} / \mathrm{mL}$ for metoprolol succinate and $5-60 \mu \mathrm{g} / \mathrm{mL}$ for telmisartan. The coefficient of correlation for metoprolol succinate and telmisartan was found to be 0.9990 and 0.9980 , respectively. The results of analysis have been validated statistically and by recovery studies. Both the drugs were subjected to acid, alkali and neutral hydrolysis, oxidation, dry heat, and photolytic degradation. The degradation products of telmisartan and metoprolol succinate were well resolved from the pure drugs with significant differences in the retention time values. This method can be successfully implemented for simultaneous quantitative analysis of metoprolol succinate and telmisartan in bulk drugs and formulations [15].

Braza A.J. et al. suggested development, validation and analytical error function of two chromatographic methods with fluorometric detection for determination of bisoprolol and metoprolol in human plasma, which describes two high-performance liquid chromatographic methods for the individual determination of bisoprolol and metoprolol in human plasma. Analytical methods involve two different liquidliquid extractions of human plasma, with diethyl ether for bisoprolol and with dichloromethane for metoprolol, coupled with a similar Nucleosil C(18) reversed-phase HPLC column. Fluorimetric detection was used to identify both betablockers. Retention times for bisoprolol and metoprolol were 8.7 and 3.2 min, respectively. Linear regressions for the calibration curves were linear at a concentration range of 6.25$200 \mathrm{ng} / \mathrm{mL}$. Intra- and inter-day precision coefficients of variations and accuracy bias were acceptable (within 15\%) over the entire range for both drugs. Average recovery was $89 \%$ for metoprolol and $98 \%$ for bisoprolol. Once the methods had been validated, analytical error functions were established as standard devia- tion $(\mathrm{SD} ; \mathrm{ng} / \mathrm{mL})=2.216+3.608 \times 10^{-4} \mathrm{C}^{2} \quad(\mathrm{C}=$ theoretical concentration value) and $\mathrm{SD}-(\mathrm{ng} / \mathrm{mL})=$ $0.408+0.378 \times 10^{-1} \mathrm{C}$ for bisoprolol and metoprolol, respectively. The developed methods and their associated analytical error functions would be suitable for pharmacokinetic studies and for determination of plasma concentration if posology individualization of these drugs is needed [16].

Chiu F.C. et al. have developed efficient high-performance liquid chromatographic assay for the simultaneous determination of metoprolol and two main metabolites in human urine by solid-phase extraction and fluorescence detection. The simultaneous analysis of the zwitterionic metoprolol acidic metabolite (III, $\mathrm{H} 117 / 04)$ with the basic metabolites alphahydroxymetoprolol (II, H119/66), metoprolol (I) and guanoxan (IV, internal standard) was achieved employing solid-phase extraction and isocratic reversed-phase HPLC. The analytes were extracted from urine (100 microliters) using C18 solid-phase extraction cartridges (100 mg), and eluted with aqueous acetic acid $(0.1 \%, v / v)$-methanol mixture $(40: 60, v / v$, $1.2 \mathrm{ml})$. The eluents were concentrated $(250$ microliters) under vacuum, and aliquots (100 microliters) were analyzed by HPLC with fluorescence detection at $229 \mathrm{~nm}$ (excitation) and $309 \mathrm{~nm}$ (emission) using simple isocratic reversed-phase HPLC (Novapak C18 radial compression cartridge, 4 microns, $100 \times 5 \mathrm{~mm}$ I.D.). Acetonitrile-methanol-TEA/phosphate buffer $\mathrm{pH} 3.0(9: 1: 90, \mathrm{v} / \mathrm{v})$ was employed as the eluent $(1.4 \mathrm{ml} / \mathrm{min})$. All components were fully resolved within $18 \mathrm{~min}$, and the calibration curves for the individual analytes were linear $\left(r_{2} \geq 0.996\right)$ within the concentration range of $0.25-40.0 \mathrm{mg} / \mathrm{ml}$. Recoveries for all four analytes were greater than $76 \%(n=4)$. The assay method was validated with intra-day and inter-day variations less than $2.5 \%$ [17].

Scientists Johnson R.D. and Lewis R.J. have developed a liquid chromatography with mass spectrometric detection (LC/MS) method for the simultaneous quantitation of three commonly prescribed beta-blockers, atenolol, metoprolol and propranolol. One advantage of the LC/MS method is the specificity provided by an ion trap MS. Utilizing an ion trap MS were able to conduct MS/MS and MS/MS/MS on each analyte. This method also eliminates the timeconsuming and costly derivitization step necessary during GC/MS analysis. Additionally, by utilizing this novel method, any concerns about beta-blocker metabolite and/or sample matrix 
interference are eliminated. The limits of detection for this method ranged from 0.39 to $0.78 \mathrm{ng} / \mathrm{mL}$ and the linear dynamic range was generally $1.6-3200 \mathrm{ng} / \mathrm{mL}$. The extraction efficiencies for each analyte ranged from $58 \%$ to $82 \%$. This method was successfully applied to postmortem fluid and tissue specimens obtained from victims of three separate aviation accidents [18].

A stereoselective liquid chromatographytandem mass spectrometry assay was developed and validated for quantification of S- and R-metoprolol at concentrations of 0.5-50 mic$\mathrm{rog} / \mathrm{L}$ in human plasma by Jensen B.P et al. Metoprolol was extracted from plasma by liquid-liquid extraction with ethyl acetate ( $82 \%$ recovery). Chromatographic separation of the enantiomers was achieved on a chiral Chirobiotic T column using an isocratic mobile phase consisting of methanol/acetic acid/ammonia $(100 / 0.15 / 0.15, v / v / v)$. An ion trap mass spectrometer with an electrospray interface was used for detection in the positive mode, monitoring the $\mathrm{m} / \mathrm{z}$ transition 268-->191 for metoprolol. Standard curves for S- and R-metoprolol fitted quadratic functions $(r(2)>0 r=0.9995)$ over the range of $0.5-50 \mathrm{microg} / \mathrm{L}$ in plasma, with $0.5 \mathrm{microg} / \mathrm{L}$ representing the limit of quantification. In this range, relative standard deviations were $<6 \%$ for intra-day precision and $<10 \%$ for inter-day precision. The accuracy was within the range of $92-105 \%$ [19].

A simple, rapid, sensitive and specific liquid chromatography-tandem mass spectrometry method has been developed and validated for quantification of metoprolol tartrate and ramipril in human plasma by Gowda K.V. et al. Both the drugs were extracted by liquid-liquid extraction with diethyl ether-dichloromethane (70:30, v/v). The chromatographic separation was performed on a reversed-phase $\mathrm{C} 8$ column with a mobile phase of $10 \mathrm{mM}$ ammonium formate-methanol $(3: 97, v / v)$. The protonated analyte was quantitated in positive ionization by multiple reaction monitoring with a mass spectrometer. The method was validated over the concentration range of $5-500 \mathrm{ng} / \mathrm{ml}$ for metoprolol and ramipril in human plasma. The precursor to product ion transitions of $\mathrm{m} / \mathrm{z}$ 268.0-103.10 and $\mathrm{m} / \mathrm{z} 417.20-117.20$ were used to measure metoprolol and ramipril, respectively [20].

Albers S. et al. have developed HPLC quantification of metoprolol with solid-phase extraction for the drug monitoring of pediatric patients. Chromatographic analysis was per- formed on a Spherisorb C(6) column (5 microm particle size) at ambient temperature and fluorimetric detection with an excitation wavelength of $225 \mathrm{~nm}$, and emission wavelength of $310 \mathrm{~nm}$. The mobile phase [30\% acetonitrile and $70 \% 0.25 \mathrm{~m}$ potassium acetate buffer $(\mathrm{pH} 4)$ ] was pumped with $1 \mathrm{~mL} / \mathrm{min}$. Metoprolol recovery was determined at $73.0+/-20.5 \%$, and the limit of quantitation was $2.4 \mathrm{ng} / \mathrm{mL}$. Precision values of intra- and inter-assay were below $15.5 \%$ and those for accuracy were between 90 and $110 \%$. This method was developed for monitoring and determination of pharmacokinetic parameters of metoprolol in pediatric patients and therefore metoprolol plasma concentrations in a 2-year-old child with ventricular tachycardia were reported [21].

Angier M.K. et al. suggested gas chromatographic-mass spectrometric differentiation of atenolol, metoprolol, propranolol, and an interfering metabolite product of metoprolol. Atenolol, metoprolol, and/or propranolol, with their possible metabolite(s), were re-extracted from the selected case specimens, derivatized with pentafluoropropionic anhydride (PFPA), and analyzed by gas chromatography-mass spectrometry (GC-MS). The MS spectra of these three antihypertensives and a metoprolol metabolite were nearly identical. All of the PFPA derivatives had baseline GC separation, with the exception of a metoprolol metabolite product, which co-eluted with atenolol. There were four primary mass fragments ( $\mathrm{m} / \mathrm{z} 408$, 366,202 , and 176) found with all of the PFPAbeta-blockers and with the interfering metabolite product. However, atenolol had three unique fragments ( $\mathrm{m} / \mathrm{z} 244,172$, and 132), metoprolol had two unique fragments ( $\mathrm{m} / \mathrm{z} 559$ and 107), propranolol had four unique fragments ( $\mathrm{m} / \mathrm{z} 551,183,144$, and 127), and the metoprolol metabolite product had two unique fragments ( $\mathrm{m} / \mathrm{z} 557$ and 149). These distinctive fragments were further validated by using a computer program that predicts logical mass fragments and performing GC-MS of deuterated PFPA-atenolol and PFPA-propranolol and of the PFPA-alpha-hydroxy metabolite of metoprolol. By using the unique mass fragments, none of the pilot fatality cases were found to contain more than one beta-blocker. Therefore, these mass ions can be used for differentiating and simultaneously analyzing these structurally similar beta-blockers in biological samples [2224].

From the above-mentioned, chromatographic methods of analysis amongst others 
have the greatest specificity and objectivity and allow qualitative and quantitative determination of API in combinate dosage forms and biological fluids without prior separation of the components. We can conclude that analysts are constantly working on developing new methods of analysis and their optimization in order to save time and consumables, which also ensures the efficiency of the developed method. The main disadvantage of the described methods of API analysis can be considered long term from the beginning of chromatography to API release and specific solvents used as the mobile phase in HPLC. It is necessary to develop methods and to select such chromatographic conditions that provide high speed and high efficiency at lower pressure of the system. This reduces the amount of used mobile phase, which reduces cost analysis accordingly, while at the same time providing the necessary specificity, accuracy and reproducibility of the results of the analysis during quality control. Also, the reduction of analysis time is achieved by simplifying the conditions for sample preparation.

\section{Conclusions}

Thus, analysts are constantly working on developing new methods of analysis and their optimization in order to save time and consumables, which also ensures efficiency of the developed method. There is no monograph on the substance or dosage forms of metoprolol in SPhU. Therefore, it would be appropriate to recommend some of the developed methods for the SPhU monograph, which is important for ensuring pharmacopeial quality control of medicines in Ukraine.

\section{Funding}

This research received no external funding.

\section{Conflict of Interests}

The authors declare no conflict of interest.

\section{Author Contributions}

Horyn M.M. - formal analysis, investigation, writing - original draft, Logoyda L.S. -conceptualization, supervision, writing - review \& editing.

\title{
МЕТОДИ АНАЛІЗУ МЕТОПРОЛОЛУ У ЛІКАРСЬКИХ ЗАСОБАХ ТА БІОЛОГІЧНИХ РІДИНАХ: ОГЛЯД ЛІТЕРАТУРИ ТА МОЖЛИВІ ШЛЯХИ ЗАСТОСУВАННЯ
}

\author{
М.М. Горин, Л.С. Логойда \\ ТЕРНОПІЛЬСЬКИЙ НАЦІОНАЛЬНИЙ МЕДИЧНИЙ УНІВЕРСИТЕТ IМЕНІ І. Я. ГОРБАЧЕВСЬКОГО, \\ ТЕРНОПІЛЬ, УКРАЇНА
}

Вступ. Розробка аналітичних методів все більше впроваджується у основні практики фармацевтичної хімії та фармацевтичного аналізу з урахуванням їх високої чутливості, точності, специфічності та відтворюваності.

Мета роботи. Критеріями пошуку була розробка аналітичного методу метопрололу.

Методи. Огляд літератури було проведено упродовж 1990-2019 років, щоб зробити огляд оновленим та всеосяжним та показати нові підходи до розробки методів аналізу метопрололу. Джерелами були визнані всесвітньо журнали, а ключовими словами, які використовувались як фільтр, були метопролол, спектрофотометрія, високоефективна рідинна хроматографія, кількісний аналіз, розробка методів, валідація.

Результати. Хроматографічні методи аналізу, серед інших, мають найбільшу специфіку та об'єктивність та дозволяють якісно та кількісно визначити активний фармацевтичний інгредієнт (АФІ) в комбінованих лікарських формах та біологічних рідинах без попереднього розділення компонентів. Можна зробити висновок, що аналітики постійно працюють над розробкою нових методів аналізу таїх оптимізацією з метою економії часу та витратних матеріалів, що також забезпечує ефективність розробленого методу. Основним недоліком описаних методів аналізу АФІ можна вважати тривалий час від початку хроматографування до виходу АФІ та специфічні розчинники, що використовуються як мобільна фаза в ВЕРХ. Необхідно розробити методи та підібрати такі хроматографічні умови, які забезпечать високу швидкість та високу ефективність при нижчому тиску системи. Це зменшує кількість використовуваної мобільної фази, що відповідно зменшує аналіз витрат, одночасно забезпечуючи необхідну специфічність, точність та відтворюваність результатів аналізу під час контролю якості. Також скорочення часу аналізу досягається шляхом спрощення умов підготовки проби.

Висновки. Можна зробити висновок, що хіміки-аналітики постійно працюють над розробкою нових методик аналізу та їх оптимізацією з метою економії часу та витратних матеріалів, що також 
забезпечує ефективність розробленого методу. На даний час не має монографії на субстанцію або лікарські форми метопрололу в ДФУ. Тому було б доцільно рекомендувати деякі розроблені методики для монографії ДФУ, що є важливим для забезпечення фармакопейного контролю якості лікарських засобів в Україні.

КЛЮЧОВІ СЛОВА: метопролол; спектрофотометрія; високоефективна рідинна хроматографія; кількісний аналіз; розробка методу; валідація.

\section{Відомості про авторів}

Горин Мар'яна Миронівна - студентка 5 курсу фармацевтичного факультету Тернопільського національного медичного університету імені І.Я. Горбачевського, Тернопіль, Україна.

Логойда Лілія Святославівна - доктор фармацевтичних наук, доцент, завідувач кафедри фармацевтичної хімії Тернопільського національного медичного університету імені І.Я. Горбачевського, Тернопіль, Україна.

\section{Information about authors}

Horyn M.M. $-5^{\text {th }}$ year student of Pharmaceutical Faculty I. Horbachevsky Ternopil National Medical University, Ternopil, Ukraine.

Logoyda L.S. - PhD, DSc, Head of Department of Pharmaceutical Chemistry I. Horbachevsky Ternopil National Medical University, Ternopil, Ukraine.

ORCID 0000-0002-5252-8806, e-mail: logojda@tdmu.edu.ua

\section{References}

1. Metoprolol Succinate Extended-Release Tablets. Tablets: $25 \mathrm{Mg}, 50 \mathrm{Mg}, 100 \mathrm{Mg}$, and $200 \mathrm{Mg}$. NDA 19-962/S-032:3. Available from: https://www.accessdata.fda.gov/drugsatfda_docs/label/2006/ 019962s032lbl.pdf. Accessed 13 Jan 2019.

2. Neagoe AM, Rexhaj E, Grossman E, Messerli FH. Beta Blockers and Calcium Channel Blockers. InCardiovascular Hemodynamics 2019 (pp. 73-88). Humana, Cham.

3. U.S. National Library of Medicine. National Center for Biotechnology Information. Available from: https://pubchem.ncbi.nlm.nih.gov. Accessed 19 Jan 2019.

4. Metoprolol Succinate Extended-Release Tablets. Revision Bulletin. Expert Committee Chemical Medicines Monographs 2. Available from: https:// www.uspnf.com/sites/default/files/usp_pdf/EN/ USPNF/revisions/metoprolol-succinate-ert-rbnotice.pdf. Accessed 19 Jan 2019.

5. U.S. Pharmacopeia. Search USP29. Metoprolol Tartrate Tablets. Available from: http://www.pharmacopeia.cn/v29240/usp29nf24s0_m53550.html. Accessed 20 Jan 2019.

6. Cesme M, Tarinc D, Golcu A. Spectrophotometric Determination of metoprolol tartrate in pharmaceutical dosage forms on complex formation with Cu(II). Pharmaceuticals (Basel). 2011;4(7):964-75.

doi: 10.3390/ph4070964

7. Nabil AF, Eman MS. Spectrophotometric determination of metoprolol in pharmaceutical formulation by charge transfer complexation. International Journal of Chemical Studies. 2015;3(2):24-9.

8. Donchenko A, Vasyuk S. Spectrophotometric determination of metoprolol tartrate in pure and dosage forms. J. Fac. Pharm. Ankara. 2018;42(1):33-42.

9. Yilmaz B. Determination of metoprolol in pharmaceutical preparations by zero-, first-, second- and third-order derivative spectrophotometric method. Int J of Pharma and Bio Sci. 2010;12(1):1-15.

10. Jadhav AS, Tarkase KN, Deshpande AP. Quantitative determination of metoprolol succinate in bulk and tablet Dosage form through comparative study of UV and derivative Spectroscopy. Der Pharmacia Lettre. 2012;4(3):763-7.

11. Rahman N, Rahman H, Aami SN. Validated Kinetic Spectrophotometric Method for the Determination of Metoprolol Tartarate in Pharmaceutical Formulations. Chem. Pharm. Bull. 2005;53(8):942-8. doi: $10.1248 / c p b .53 .942$

12. Hussain S, Munjewar RR, Farooqui M. Development and validation of a simultaneous HPLC method for quantification of amlodipine besylate and metoprolol tartrate in tablets. Journal of Pharmascitech. 2012;1(2):1-5.

13. Singh BK, Patel DK, Ghosh SK. Development of Reverse-Phase HPLC method for simultaneous analysis of metoprolol succinate and hydrochlorothiazide in a tablet formulation. Tropical Journal of Pharmaceutical Research. 2009;8(6):539-43.

doi: 10.4314/tjpr.v8i6.49401

14. Prasad PH, Patel PM, Vijaysree D, Reddy YS, Ranjith Kumar B. Simultaneous estimation of metoprolol tartrate and chlorthalidone by using RP-HPLC and method development as per ICH guidelines. Der Pharma Chemica. 2013;5(5):139-43.

15. Mahaparale SP, Gonjari ID, Jayaveera KN. Stability indicating HPLC method for simultaneous estimation of metoprolol succinate and termisartan. Journal of Liquid Chromatography \& Related Technologies. 2013;36:2601-11.

doi: 10.1080/10826076.2012.723095

16. Braza AJ, Modamio P, Lastra CF, Marino EL. Development, validation and analytical error function of two chromatographic methods with fluorometric 
detection for the determination of bisoprolol and metoprolol in human plasma. Biomed Chromatogr. 2002;16:517-22.

doi: 10.1002/bmc.195

17. Chiu FCK, Damani LA, Li RC, Tomlinson B. Efficient high-performance liquid chromatographic assay for the simultaneous determination of metoprolol and two main metabolites in human urine by solid-phase extraction and fluorescence detection. J Chromatogr B. 1997;696:69-74.

doi: 10.1016/S0378-4347(97)00059-5

18. Johnson RD, Lewis RJ. Quantitation of atenolol, metoprolol, and propranolol in postmortem human fluid and tissue specimens via LC/APCI-MS. Forensic Sci Int. 2006;156:106-17.

doi: 10.1016/j.forsciint.2005.01.001

19. Jensen BP, Sharp CF, Gardiner SJ, Begg EJ. Development and validation of a stereoselective liquid chromatography tandem mass spectrometry assay for quantification of $\mathrm{S}$ and R-metoprolol in human plasma. J Chromatogr B. 2008;865:48-54.

doi: 10.1016/j.forsciint.2005.01.001

20. Gowda KV, Mandal U, Selvan PS, Solomon WDS, Ghosh A, Sarkar AK, et al. Liquid chromatography tandem mass spectrometry method for simultaneous determination of metoprolol tartrate and ramipril in human plasma. J Chromatogr B. 2007;858:13-21. doi: 10.1016/j.jchromb.2007.07.047
21. Albers S, ElshoffJP, Volker C, Richter A, Laer S. HPLC quantification of metoprolol with solid-phase extraction for the drug monitoring of pediatric patients. Biomed Chromatogr. 2005;19:202-7.

doi: 10.1002/bmc.436

22. Angier MK, Lewis RJ, Chaturvedi AK, Canfield DV. Gas chromatographic-mass spectrometric differentiation of atenolol, metoprolol, propranolol, and an interfering metabolite product of metoprolol. J Anal Toxicol. 2005;29:517-21.

doi: $10.1093 /$ jat/29.6.517

23. Logoyda L. Analysis of approaches to the development and validation of the methods of analysis of some active pharmaceutical ingredients from the group of calcium channel blockers in drugs and biological liquids. International Journal of Applied Pharmaceutics. 2019;11(3):26-34.

doi: 10.11603/mcch.2410-681X.2019.v.i3.10566

24. Logoyda L. Analysis of approaches to the development and validation of the methods of analysis of some active pharmaceutical ingredients from the group of angiotensin converting enzyme inhibitors in drugs and biological liquids. International Journal of Applied Pharmaceutics. 2019;11(4):1-7. doi: 10.22159/ijap.2019v11i4.32420

Received 07 September 2019; revised 19 October 2019; accepted 25 November 2019.

This is open access article distributed under the Creative Commons Attribution License, which permits unrestricted use, distribution, and reproduction in any medium, provided the original work is properly cited. 